Research Article (Araştırma Makalesi)

\section{Neslihan KALKAN}

Servet YALÇIN

(-0000-0002-9548-2027

(10000-0003-4194-0536

Ege University, Faculty of Agriculture, Department of Animal Science, 35100, Bornova, Izmir, Turkey

Corresponding author: neslihankalkan@gmail.com

\section{Keywords:}

Sustainability, standardized data, egg production, conventional cage, organic, free-range.

\section{Anahtar Kelimeler:}

Sürdürülebilirlik, standartlaştırılmış veri, yumurta üretimi, geleneksel kafes, organik, serbest gezinmeli.

\section{Evaluating the Sustainability of Egg Production in Turkey: A Standardized Data Approach}

\author{
Türkiye'de Yumurta Üretiminin Sürdürülebilirliğinin \\ Değerlendirilmesi: Standartlaştırılmış Veri Yaklaşımı
}

Alını̧̧ (Received): 13.07.2020

Kabul tarihi (Accepted): 09.12.2020

\begin{abstract}
Objective: This study aimed to evaluate egg production systems within the scope of sustainability criteria under Turkey conditions.

Materials and Methods: A standardized data approach was used to measure sustainability and compare egg production systems. The study covered a one-year egg-laying cycle of 24 farms including conventional cage, organic, and free-range systems.

Results: Hens in conventional cages had higher egg production and lower feed intake compared to hens in organic and free-range systems. The highest mortality was found in the free-range hens while the lowest was in the conventional cage system. All hens were fully feathered in the organic egg production system, which was followed, by free-range and conventional cage. This result led to a better social sustainability score for non-cage systems. Economic issues of sustainability had higher scores in conventional cage and organic egg production than those in the free-range system. The hen number per $\mathrm{m}^{2}$ in the total farm area was lower in organic and free-range than those in conventional cage systems $(P=0.003)$, nonetheless, the total land occupation area was found similar.
\end{abstract}

Conclusion: The high scores obtained for economic and environmental indicators of sustainability in conventional cage system led to the highest total sustainability score. The management practices should be improved in free-range and organic egg production systems to achieve higher sustainability scores in Turkey.

\section{öz}

Amaç: Bu çalışmada ülkemiz koşullarındaki yumurta üretim sistemlerinin sürdürülebilirliğin değerlendirilmesi amaçlanmıştır.

Materyal ve Yöntem: Yumurta üretim sistemlerini karşılaştırmak ve sürdürülebilirliği ölçmek için standartlaştırılmış veriler kullanılmıştır. Çalışmada geleneksel kafes, organik ve serbest gezinmeli sistemde yumurta üreten toplam 24 adet işletmenin bir yumurta verim dönemi verilerinden yararlanılmıştır.

Bulgular: Geleneksel kafeslerdeki tavukların yumurta verimi, organik ve serbest gezinmeli sistemlerdeki tavuklara kıyasla daha fazla olup kafes yetiştiriciliğinde yem tüketimi diğer sistemlere göre daha düşük bulunmuştur. En yüksek ölüm oranı serbest gezinmeli sistem tavuklarında bulunurken, en düşük ölüm oranı ise geleneksel kafes sisteminde olmuştur. Organik üretimde tüm tavukların tüylenmeleri tam olup, bunu serbest gezinmeli ve geleneksel kafes sistemleri izlemiştir. Bu sonuç kafessiz sistemler için daha iyi bir sosyal sürdürülebilirlik skoru elde edilmesini sağlamıştır. Sürdürülebilirliğin ekonomik unsurları açısından, geleneksel kafes ve organik yumurta üretimi, serbest gezinmeli sisteme göre daha sürdürülebilir bulunmuştur. Toplam çiftlik alanı içinde birim alana düşen tavuk sayısı organik ve serbest gezinmelide geleneksel kafes sistemine göre daha düşük bulunmuştur $(P=0.003)$, buna rağmen toplam arazi işgal alanının benzer olduğu saptanmıştır.

Sonuç: Sonuç olarak, sürdürülebilirliğin ekonomik ve çevresel göstergeleri açısından geleneksel kafes sistemi daha sürdürülebilir bulunurken toplam sürdürülebilirlik puanı da diğer üretim sistemlerine göre yüksek olmuştur. Türkiye'de serbest gezinmeli ve organik yumurta üretimi yapan işletmelerde bakım-yönetim koşullarının iyileştirilmesi gerektiği yargısına varılmıştır. 


\section{INTRODUCTION}

The world's current population of 8 billion people is expected to reach to 9.6 billion by 2050 . This increase in population leads to increased demand for protein. Recent studies concluded that animal-based protein is necessary for a sustainable diet compared to vegan diets, moreover, human-digestible protein can be produced more efficiently by livestock animals than crops (Van Kernebeek et al., 2016; van Zanten et al., 2016).

The egg is one of the major dietary sources of animal protein. Worldwide egg production was average of 80 million tons in 2017 (FAO, 2017). Increased consumer awareness of environmental and animal welfare concerns has contributed to the conversion of conventional cages to enriched cages and the growth of alternative non-cage systems such as organic and free-range egg production. In 2017, the number of laying hens in enriched cages was 200.2 million (50.3\%) while it was $21.6(5.4 \%)$ and 64.7 million (16.3\%) in organic and free-range systems in the European Union countries (Commission Implementing Regulation, 2017).

In Turkey, there are 127.372.689 laying hens and 3211 farms for egg production (Yum-Bir, 2018). The conventional cage system is the predominant housing system in Turkey, however, it will be banned starting in 2023. In 2018, about 22 billion eggs were produced commercially, approximately 160 million and 1.1 million of the total production were organic and freerange, respectively (Yum-Bir, 2018). Comparing to the cage system, relatively small- or medium scale farmers are being dealt with these non-cage egg production systems (Kalkan, 2019).

The future of egg production will be depended on sustainability. Studies on sustainability in egg production focus on environmental, economic or welfare issues of different poultry production systems (Mollenhorst et al., 2006; Xin et al., 2011; Dekker et al., 2011; Summer et al., 2011; Leinonen et al., 2014; Shepherd et al., 2015; van Asselt et al., 2015). Mollenhorst et al. (2005) suggested using on farm sustainability indicators; such as performance (economic aspect), animal welfare (social aspect), and cost of electricity (environmental aspect) to identify strengths and weakness of the systems. Previous studies developed an overall sustainability score to compare the overall sustainability of the chicken meat (Castellini et al., 2012) and egg (van Asselt et al., 2015) production systems using different methods.

Although Turkey is one of the largest egg producers worldwide, there is no study conducted on the sustainability of egg production in Turkey. The purpose of our study was to determine economic, environmental, and social indicators of sustainability of current egg production systems in different housing systems under Turkey conditions. A standardization was used to enable incorporate economic, social, and environmental aspects of sustainability in the conventional cage, organic, and free-range egg production systems. The sustainability score was calculated for each production system.

\section{MATERIALS AND METHODS}

\section{Data collection}

The data were collected one full laying cycle from commercial egg producers in the Adapazarı, Afyon, İzmir, Konya, Aydın, Balıkesir and Çanakkale provinces in Turkey. This area was chosen due to its high density of layer farms. A list of commercial layer farms was created from various sources and randomly selected farms were conducted via telephone or email to request to participate in the project. A total of 24 farms, including 6 organic, 7 free-range, and 11 conventional cage systems, were accepted to participate. The conventional cage system consisted of wire cages with nipple drinkers, feeders, egg belts, and manure belts. A total floor area of $375-400 \mathrm{~cm}^{2}$ was provided per birds in each cage. In organic production, hens were housed in a poultry house with automatic drinkers and feeders and wood-shaving or rice husk litter. There were 9 chickens per square meter in the house with free access to a pasture area. The hens fed a diet consisting of "organic certificated" ingredients. The free-range production had similar indoor characteristics to an organic system with free access to pasture.

Within the sustainability context, egg production, feed consumption, dirty and cracked eggs, and egg price data were evaluated as economic sustainability. Animal welfare criteria such as mortality rate, freerange area, and feather score were evaluated as an indicator of social sustainability. A "without handling the animals" method adapted from AssureWel (2013) was used to measure feather score. Briefly, a total of 10 different points and 5 hens/points were chosen in the house to feather score the hens. Score " 0 " was no feather loss or no visible bare skin; score "1" was intended for moderate wear, damaged feathers or feathers missing up to of maximum $5 \mathrm{~cm}$ visible bare skin; score "2" referred to those with severe feather loss with larger than $5 \mathrm{~cm}$ visible skin. Land occupation, the costs of electricity and water usage 
(monthly cost for 1000 hens in Euro) were examined for environmental sustainability.

\section{Statistical analysis, standardization \& scoring}

Different statistical models were used in the evaluation of the results using the statistical analysis software of JPM (SAS Institute, 2002). One-way ANOVA was used to evaluate rearing systems on economic, social, and environmental criteria. Since the conventional cages do not have a free-range area, these farms were not included in free pasture area analysis. Chi-square was used to evaluate the feather score of laying hens. Where significant differences existed among production systems, means were separated by student t-test.

All variables for each production system were standardized transforming the data to one with a mean of 0 and a standard deviation of 1 (Sauro and Kindlund, 2005). Standardized data were used to calculate the sustainability score for each production system. The negative values indicated a negative contribution. The scores obtained for economic, social, and environmental issues were used to calculate the total sustainability score for each production system. The system, which gained the highest score, was defined as more sustainable compared to the others.

\section{RESULTS}

\section{Economic issues}

Egg production, daily feed intake, and one dozen egg prices significantly differed with egg production systems $(P<0.05)$. Higher egg production was obtained in cage system than in free-range while eggs from organic farms were intermediate (Table 1). Feed intake hen/per day was higher in organic and freerange systems than in conventional cages. No differences were observed among the systems for daily cracked and dirty eggs. One dozen egg price was similar for organic and free-range systems, being more expensive than those eggs from conventional (Table 1).

Table 1. Sustainability indicators of the egg production systems Çizelge 1. Yumurta üretim sistemlerinin sürdürülebilirlik göstergeleri

\begin{tabular}{|c|c|c|c|c|c|}
\hline & \multicolumn{3}{|c|}{ Production system } & \multicolumn{2}{|c|}{ Statistical analysis } \\
\hline & Conventional cage & Organic & Free-range & SEM $^{1}$ & $P$ \\
\hline \multicolumn{6}{|l|}{ Economic indicators } \\
\hline Egg production, hen & $314^{a}$ & $280^{\mathrm{ab}}$ & $253^{b}$ & 11 & 0.001 \\
\hline Daily feed intake, hen/d, g & $114^{\mathrm{b}}$ & $120^{\mathrm{a}}$ & $124^{\mathrm{a}}$ & 2 & 0.050 \\
\hline Daily cracked eggs, \% & 0.56 & 0.41 & 1.02 & 0.20 & 0.264 \\
\hline Daily dirty eggs, \% & 0.45 & 0.65 & 1.87 & 0.24 & 0.204 \\
\hline One dozen egg price, $€$ & $0.51^{b}$ & $1.06^{a}$ & $1.17^{\mathrm{a}}$ & 0.07 & $<0.001$ \\
\hline \multicolumn{6}{|l|}{ Social indicators } \\
\hline Mortality, \% & $5.99^{b}$ & $9.02^{\mathrm{ab}}$ & $12.06^{\mathrm{a}}$ & 1.54 & 0.017 \\
\hline Free pasture area ( $\mathrm{m}^{2}$ per hen) & - & 4.94 & 4.51 & 2.0 & 0.911 \\
\hline \multicolumn{6}{|l|}{ Environmental indicators } \\
\hline Electricity, 1000 hen/month, $€$ & $14.6^{\mathrm{b}}$ & $24.3^{a b}$ & $41.3^{\mathrm{a}}$ & 0.03 & 0.019 \\
\hline Water, 1000 hen/month, $€$ & 8.87 & 9.97 & 9.20 & 1.5 & 0.847 \\
\hline Total land occupation, ha & 1.91 & 2.01 & 2.53 & 0.30 & 0.788 \\
\hline Hen number $/ \mathrm{m}^{2}$ in total farm area & $2.31^{\mathrm{a}}$ & $0.23^{b}$ & $0.21^{\mathrm{b}}$ & 0.08 & 0.003 \\
\hline
\end{tabular}

Means in the same row with no common superscript differ significantly $(P<0.05)$.

${ }^{1} \mathrm{SEM}=$ Standard error of mean.

\section{Social issues}

Production system had a significant effect on mortality ( $P=0.01$, Table 1$)$. The highest mortality was found in the free-range and the lowest was in the conventional cage system. Free pasture area was similar for organic and free-range systems. Feather condition was influenced by production systems $(P<0.001$, Figure 1$)$. All the birds in the organic system were fully feathered and had scored " 0 ". The number of hens with no feather damage was lower in conventional cage system than in free-range. Number of laying hens with score 2 was 88.9 and $13.7 \%$ for conventional cage and free-range, respectively.

\section{Environmental issues}

The cost of electricity was the highest for the freerange $(\mathrm{P}=0.01)$. Water usage cost was similar among the production systems. The total land occupation area for egg production was not influenced by production systems. However, hen number per $\mathrm{m}^{2}$ in the total farm area was lower in organic and freerange systems than in conventional cages (Table 1). 


\section{Sustainability score}

Illustration of the systems on contribution to sustainability is shown in Figure 2. The conventional cage system had negative sustainability scores for egg price and feather score. Cracked and dirty eggs, egg price, free pasture area, feather condition, water cost received positive scores in the organic egg production system. Positive sustainability scores were obtained in the free-range systems for egg price, free pasture area, feather condition, and water cost.

Figure 3 illustrates the total economic, social, and environmental scores of each production system.
Economic issues of the conventional and the organic systems had positive scores whereas it was negative in the free-range system. The conventional cages scored negative while the organic and free-range systems had positive scores for social issues of sustainability. The conventional cage system received the highest sustainability score for environmental issues of sustainability. The overall sustainability scores was $1.298,-0.166,-2.741$ for the conventional cage, organic and free-range systems, respectively (data not shown in Figures).

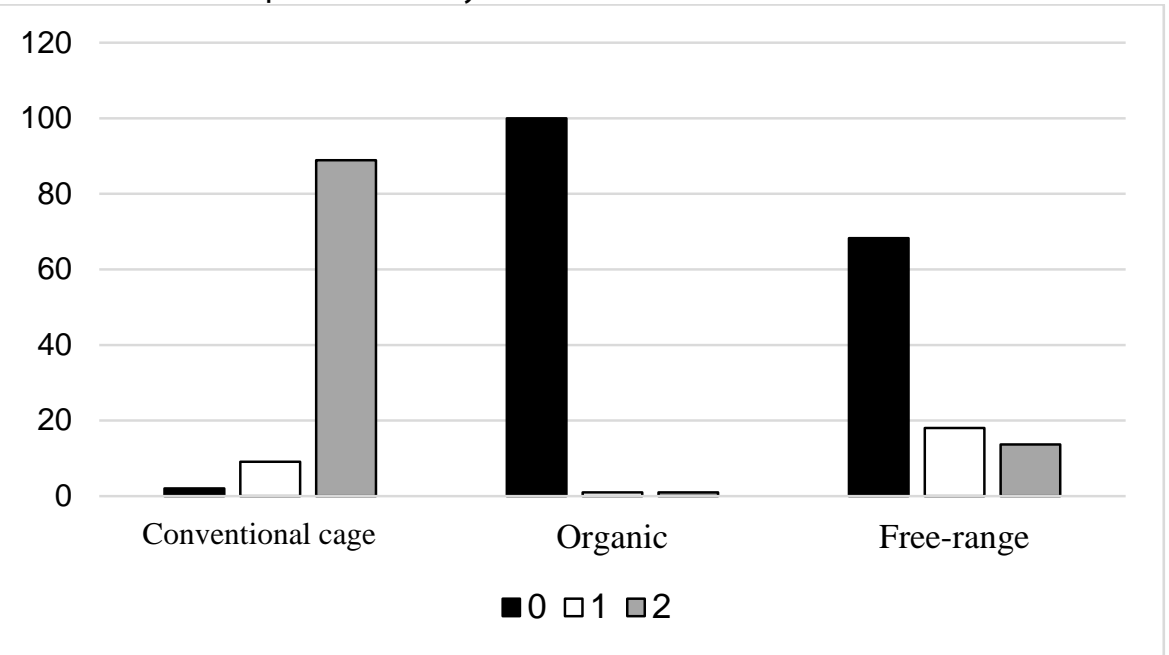

Figure 1. Feather condition of hens in different egg production systems $\left(P<0.001, X^{2}=944.556\right)(0$ : No/minimal feather loss, 1 : Moderate $<5$ $\mathrm{cm}$ dimension bare skin visible, 2 : Severe $\geq 5 \mathrm{~cm}$ dimension bare skin visible.)

Şekil 1. Yumurta üretim sistemlerinde tavukların tüylenme durumları $\left(P<0.001, X^{2}=944.556\right)(0$ : Hiç/çok az tüy kaybı, 1: Orta dereceli $<5 \mathrm{~cm}$ 'den daha az tüysüz görünür deri, 2: Şiddetli $\geq 5$ cm'den daha fazla tüysüz görünür deri)

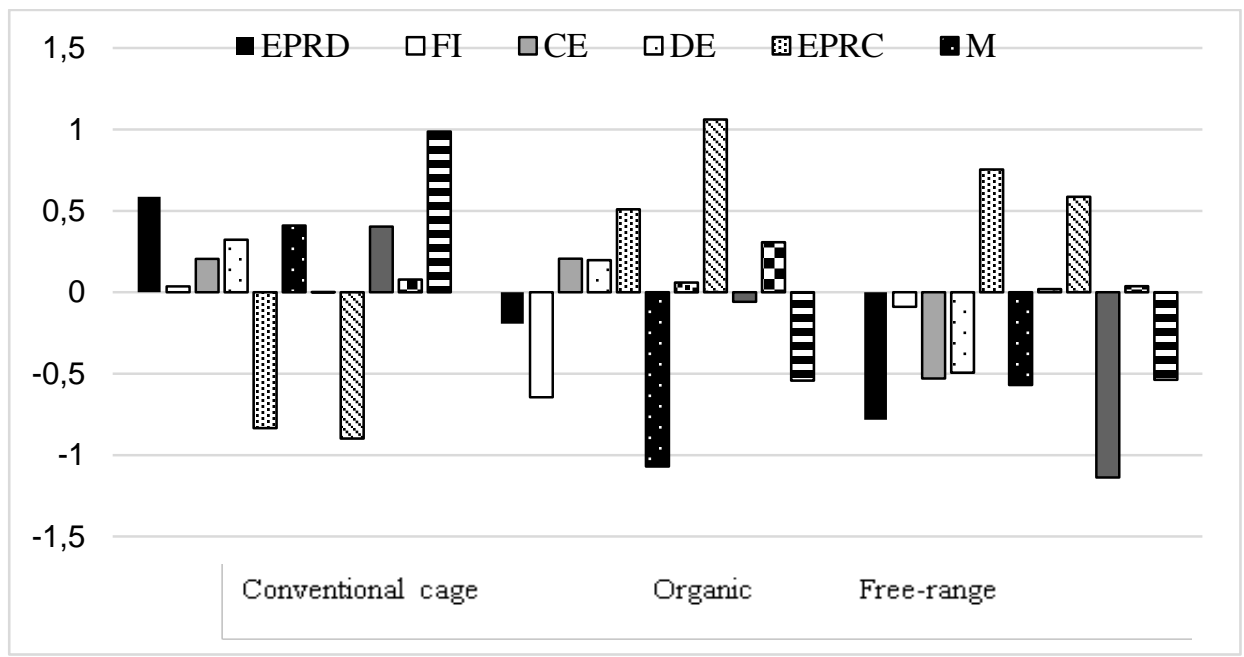

Figure 2. Sustainability score of each indicator within egg production systems

(EPRD: Egg production/hen, Fl: Daily feen intake hen/d, EPRC: One dozen egg price $€$, CE: Cracked eggs daily \%, DE: Dirty eggs daily \%, M: Mortality \%, FRA: Free pasture area $\mathrm{m}^{2} / \mathrm{hen}$, FC: feather condition, EC: Electricity cost 1000 hen/month $€$, WC: Water cost 1000 hen/month $€$, L: Hen number $/ \mathrm{m}^{2}$ in total farm area)

Şekil 2. Yumurta üretim sistemlerinin her bir gösterge için aldıkları sürdürülebilirlik puanları 
(EPRD: Yumurta verimi/tavuk, FI: Günlük yem tüketimi tavuk/g, EPRC: Bir düzine yumurta fiyatı €, CE: Günlük kırık yumurta \%, DE: Günlük kirli yumurta \%, M: Ölüm oranı \%, FRA: Serbest gezinme mera alanı $\mathrm{m}^{2} /$ tavuk, FC: Tüylenme durumu, EC: Elektrik gideri 1000 tavuk/ay $€$, WC: Su gideri 1000 tavuk/ay $€$, L: Toplam çiftlik alanındaki tavuk sayısı $/ \mathrm{m}^{2}$ )

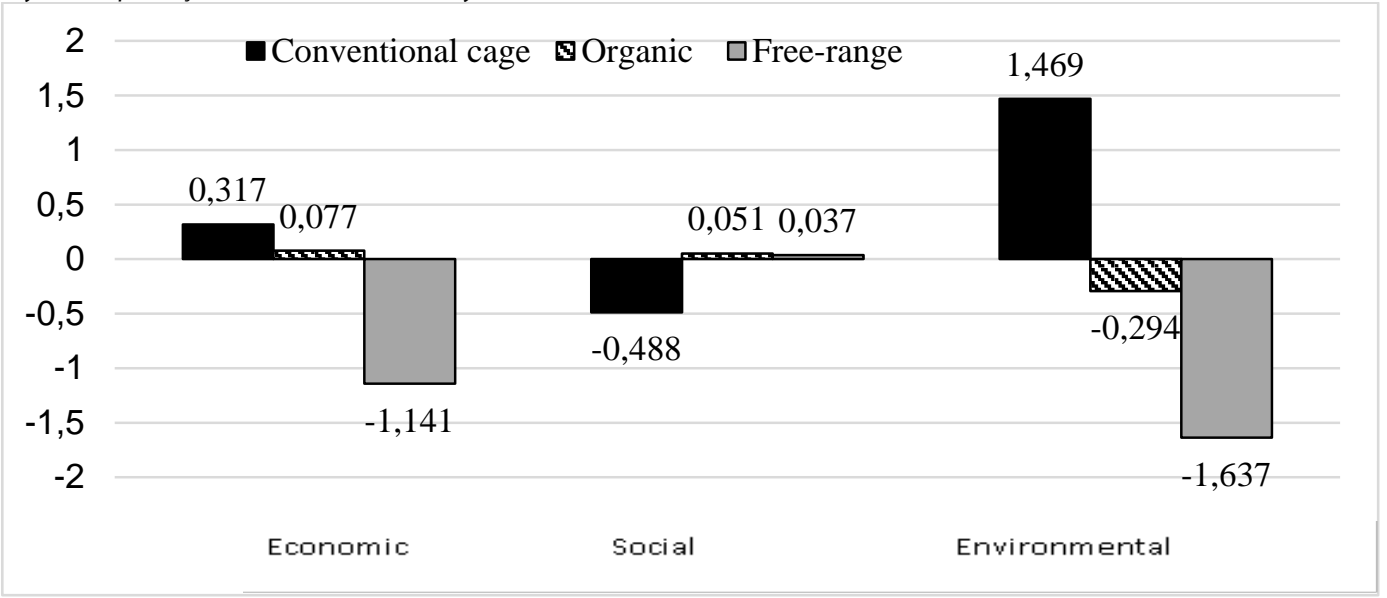

Figure 3. Sustainability scores of economic, social, and environmental issues within egg production systems

Şekil 3. Yumurta üretim sistemlerinin ekonomik, sosyal ve çevresel konulardaki sürdürülebilirlik skorları

\section{DISCUSSION}

There is an increasing emphasis on to produce eggs using animal-friendly systems and reduce mortality rate and environmental impact of production. In current commercial egg production systems, cage, or non-cage, which includes free-range, barn and organic systems are used to kept hens. Conventional cages are the most used egg production systems in Turkey, however, will be replaced with enriched cages in 2023. Parallel to the trends towards animal welfare issues, the demand for organic and free-range eggs is also growing in Turkey. To introduce these systems on a wide scale, to show 1) differences among the egg production systems and 2) contribution of the egg production systems to sustainable development is necessary. An evolution of sustainability of egg production systems in Turkey is necessary to show the variations among the indicators and systems. The objective of this study, therefore, was to compare the sustainability of current egg production systems in Turkey.

Previous studies showed that egg production tended to be lower in organic farms than in free-range (Leenstra et al., 2012; Matthews and Summer, 2015). The egg production differences among the production systems observed in this study are mostly due to the genetic strains used by farmers. Genetic stocks used for the free-range system are mostly dualpurpose or local breeds, which are less productive comparing commercial hybrids used for conventional or organic egg production. Although cracked eggs and dirty eggs produced per hen/d were similar among the production systems, free-range system had a numerically higher total number of cracked and dirty eggs than conventional cage system. This higher egg losses probably resulted from housing conditions and management system indicating that management conditions need to be improved.

Hens in non-cage systems tended to consume more feed (EFSA, 2005; van Staaveren et al., 2018). It is known that locomotor activity increases feed intake of hens. The lower stocking density and provision of perches increase activity of the hens in the non-cage systems (Sandilands et al., 2009; Regmi et al., 2016). Higher feed intake found in organic and free-range systems may be related to the hens' activity level. However, hens' behavior was not determined in the present study.

Animal welfare is known as one of the important issues of sustainability. Higher levels of mortality are associated with impaired animal health and welfare. Housing system can affect the mortality rate. Appleby and Hughes (1991) reported that hens exposed to the higher disease risk in alternative housing systems compared to cage system. In a survey in the UK, mortality rate, including culled birds, changed between 1.8 to $21.4 \%$ when the hens were housed on the floor (Whay et al., 2007). Weeks et al. (2016) reported a higher mortality rate for free-range systems compared to conventional cages. Because the cage systems provide a cleaner environment to the hens, cages have a positive effect on hens' health (de Boer et al 2002). Being agreed with the previous studies, mortality was also higher in the organic and freerange systems in our study. Management, flock size and age, genotype, and vaccination differences cause 
variation in the incidence of total mortality (Weeks et al., 2016). The breeds used in the free-range system is mostly local breeds and could be expected to be more resistant to environmental conditions; however, this was not the case and the higher mortality rate in organic and free-range $(9.02$ and $12.06 \%$, respectively) systems could be attributed to the biosecurity and vaccination program.

One of the weaknesses of the conventional cage systems is a negative effect on animal welfare, due to the inability to exhibit their behavior repertoire, absence of nest, litter, and perch. Feather condition is considered as a welfare indicator (Weeks and Nicol, 2006). Blokhuis et al. (2007) and Leenstra et al. (2012) reported that hens reared on the floor had better feather conditions. Similarly, our results showed that the feather condition was better in hens on the floor, however, hens in an organic production system had a better feather condition than hens in free-range. Bilcik and Keeling (2010) showed that the number of severe feather pecks was related to feather damage. In the present study, most of the plumage damage for hens in free-range was observed on the breast region, which could not be attributed to the feather pecking. Perch design might be an affecting factor of feather damage.

Organic and free-range systems increased electricity usage 1.66 and 2.82 times compared to the conventional cages. Xin et al. (2011) found that the land occupation per kilogram of eggs was the lowest in the conventional cage and highest in the organic system. In our study, although land occupation was similar among the production systems, land occupation per hen was better in conventional cages. This result showed that the hens in organic and freerange systems have already a large farm area in Turkey, however, the birds do not utilize it efficiently. Advancement in housing technology for conventional cage systems led to keep thousands of hens in a single house and increased efficiency of land usage for the hen $/ \mathrm{m}^{2}$ farm area. Similarly, Mench and Rodenburg (2018) reported that non-cage systems have reduced resource usage efficiency such as energy and land. The higher electricity and land occupation in organic and free-range systems compared to conventional cage may be related to the lower stocking density of those systems.

\section{REFERENCES}

Appleby M C and Hughes B O. 1991. Welfare of laying hens in cages and alternative systems: environmental, physical and behavioral aspects. World's Poultry Science Journal 47:109-128.
Developing a sustainability score is necessary to compare the egg production systems. van Asselt et al. (2015) compared sustainability of enriched cage, barn, free-range, and organic egg production systems and reported that enriched cage system had the highest sustainability score, free-range and organic systems were between enriched cage and barn system. In the present study, standardized data was used to obtain sustainability score, herewith-negative scores would indicate a contribution to sustainability was failed. As expected, none of the egg production systems was sustainable for all issues of sustainability. The results showed that both organic and economic egg production systems had positive scores for economic aspects. This better economic income was related to higher egg production in these systems compared to the free-range system. Organic and free-range egg production systems had better scores in terms of the social aspect of sustainability, which was due to better feather scores. The results also showed that high mortality and high land usage associated with lower sustainability scores of organic and free-range systems under Turkey conditions. In the present study, high scores obtained for economic and environmental issues of sustainability in conventional egg production led to the highest total sustainability score.

\section{CONCLUSION}

In conclusion, like the egg production sector in European countries, the Turkish egg industry will experience the changes in egg production systems. Efforts to understand the current sustainability of egg production is requested to design a future state. However, there are advantages and disadvantages of all systems studied in the present study. Problems arising from free-range and organic systems include higher feed intake, mortality, lower egg production, and lower land usage efficiency. These results indicated that management practices should be improved in free-range and organic egg production systems in Turkey.

\section{ACKNOWLEDGEMENTS}

This manuscript is a part of first author's master thesis. The authors would like to thank to the Ege University BAP Commission for the financial support (17-FBE-003).

AssureWel. 2013. Laying hen welfare outcome assessment explanation of measures. http://www.assurewel.org/layinghens/featherloss (10 February 2020). 
Bilcik B and Keeling LJ. 1999. Changes in feather condition in relation to feather pecking and aggressive behaviour in laying hens. British Poultry Science 40(4):444-451.

Blokhuis HJ, Van Niekerk TF, Bessei W, Elson A, Guémené D, Kjaer JB, Maria Levrino GA, Nicol CJ, Tauson R, Weeks CA and Van de Weerd HA. 2007. The LayWel project: welfare implications of changes in production systems for laying hens. World's Poultry Science Journal 63:101-114.

Castellini C, Boggia A, Cortina C, Dal Bosco A, Paolotti L, Novelli E, and Mugnai C. 2012. A multicriteria approach for measuring the sustainability of different poultry production systems. Journal of Cleaner Production 37:192-201.

Commission Implementing Regulation. 2017. Methods of production communicated according to Commission Implementing Regulation (EC-617/2008). European Commission (DG ESTAT, DG AGRI), 2017/1185.

de Boer JM and Cornelissen AMG. 2002. A method using sustainability Indicators to compare conventional and animalfriendly egg production systems. Poultry Science 81:173-181.

Dekker SEM, de Boer IJM, Vermeij I, Aarnink AJA, \& Groot Koerkamp PWG. 2011. Ecological and economic evaluation of Dutch egg prodcution systems. Livestock Science 139:109-121.

EFSA (The European Food Safety Authority). 2005. Opinion of the Scientific Panel on Animal Health and Welfare on a request from the Commission related to the welfare aspects of various systems of keeping laying hens. EFSA Journal 197:1-23.

FAO. 2017. http://www.fao.org/faostat/en/\#data/QL (10 February 2020).

Kalkan N. 2019. Sustainability of broiler meat and egg production systems. Master Thesis, Ege University (Unpublished), Turkey.

Leenstra F, Maurer V, Bestman M, van Sambeek F, Zeltner E, Reuvekamp B, Galea F, and van Niekerk T. 2012. Performance of commercial laying hen genotypes on free range and organic farms In Switzerland, France and The Netherlands. British Poultry Science 53:282-290.

Leinonen I, Williams A G, and Kyriazakis I. 2014. The effects of welfare-enhancing system changes on the environmental impacts of broiler and egg production. Poultry Science 93:256-266.

Matthews WA and Sumner DA. 2015. Effects of housing system on the costs of commercial egg production. Poultry Science 94:552-557.

Mench JA and Rodenburg TB. 2018. Sustainability of laying hen housing systems. In: Mench J (Ed.), Advances in poultry welfare Woodhead Publishing, pp.199-225.

Mollenhorst H, Berentsen PBM, \& de Boer IJM (2006). On-farm quantification of sustainability indicators: an application to egg production systems. British Poultry Science 47(4):405-417.

Mollenhorst H, Rodenburg TB, Bokkers EAM, Koene P, and de Boer IJM. 2005. On-farm assessment of laying hen welfare: a comparison of one environmental-based and two animal-based methods. Applied Animal Behavior Science 90:277-291.
Regmi P, Smith N, Nelson N, Haut RC, Orth MW, and Karcher DM. 2016. Housing conditions alter properties of the tibia and humerus during the laying phase in Lohmann white Leghorn hens. Poultry Science 95(1):198-206

Sandilands V, Moinard C, and Sparks NHC. 2009. Providing laying hens with perches: fulfilling behavioral needs but causing injury? British Poultry Science 50:395-406.

SAS INSTITUTE. 2002. JMP® User's Guide: Statistics Version 5.0.1. edition, Cary, NC. SAS Institute.

Sauro J and Kindlund E. 2005. A method to standardize usability metrics into a single score. Proceedings of the SIGCHI Conference on Human Factors in Computing Systems: 401-409.

Shepherd TA, Zhao Y, Li H, Stinn JP, Hayes MD, and Xin H. 2015. Environmental assessment of three egg production systems- Part II Ammonia, greenhouse gas, and particulate matter emissions. Poultry Science 94:534-543.

Sumner DA, Gow H, Hayes D, Matthews W, Norwood B, RosenMolina JT and Thurman W. 2011. Economic and market issues on the sustainability of egg production in the United States: analysis of alternative production systems. Poultry Science 90:241-250.

van Asselt ED, van Bussel LGJ, van Horne P, van der Voet $H$, van der Heijden GWAM, and van der Fels-Klerx HJ. 2015. Assessing the sustainability of egg production systems in The Netherlands. Poultry Science 94:1742-1750.

Van Kernebeek HRJ, Oosting SJ, Van Ittersum MK, Bikker P and de Boer IJM. 2016. Saving land to feed a growing population: consequences for consumption of crop and livestock products. The International Journal of Life Cycle Assessment 21:677-687.

van Staaveren N, Decina C, Baes FC, Widowski TM, Berke O, and Harlander-Matauschek A. 2018. A description of laying hen husbandry and management practices in Canada. Animals 8:114

van Zanten BT, Zasada I, Koetse MJ, Ungaro F, Häfner K, and Verburg PH. 2016. A comparative approach to assess the contribution of landscape features to aesthetic and recreational values in agricultural landscapes. Ecosystem Services 17:87-98.

Weeks CA, and Nicol CJ. 2006. Behavioural needs, priorities and preferences of laying hens. World's Poultry Science Journal 62:296 307.

Weeks CA, Lambton SL, and Williams AG. 2016. Implications for welfare, productivity and sustainability of the variation in reported levels of mortality for laying hen flocks kept in different housing systems: a meta- analysis of ten studies. PLoS ONE 11(1):1-15.

Whay HR, Main DCJ, Green LE, Heaven G, Howell H, Morgan M, Pearson A, and Webster A J F. 2007. Assessment of the behaviour and welfare of laying hens on free-range units. Veterinary Record 161:119-128

Xin H, Gates RS, Green AR, Mitloehner FM, Moore Jr. PA, and Wathes CM. 2011. Environmental impacts and sustainability of egg production systems. Poultry Science 90:263-277.

Yum-Bir. 2018. https://www.yum-bir.org/Yumurta/id30-Istatistikler (10 February 2020). 